\title{
Chemical Composition and Cytotoxic Activity of Pistacia atlantica var. kurdica Fruits
}

\author{
Raad A. Kaskoos ${ }^{1}$, Javed Ahamad ${ }^{2}$, Subasini Uthirapathy ${ }^{3}$ \\ ${ }^{1}$ Department of Pharmacy, Al-Manara College for Medical Science, \\ Amarah, Iraq \\ ${ }^{2}$ Department of Pharmacognosy, Faculty of Pharmacy, Tishk International University, \\ Erbil, Kurdistan Region, Iraq \\ ${ }^{3}$ Department of Pharmacology, Faculty of Pharmacy, Tishk International University, \\ Erbil, Kurdistan Region, Iraq
}

\begin{abstract}
Pistacia atlantica var. kurdica (Anacardiaceae) is a major subspecies found in the Kurdistan region of Iraq and has several beneficial bioactivities such as antioxidant, antibacterial, and antiviral. $P$. atlantica growing in the Kurdistan region is not yet studied phytochemically and pharmacologically. Hence, the goal of the present study is to characterize chemical compounds present in ethanolic extract of $P$. atlantica fruits by gas chromatography-mass spectroscopy (GC-MS) and to evaluate cytotoxic activity using A549 (human lung cancer) cell lines by (3-4,5 dimethylthiazol-2yl2,5-diphenyl tetrazolium bromide) assay. The GC-MS analysis shows the presence of 33 chemical compounds which constitute about $\mathbf{9 9 . 9 5 \%}$ of total compounds, and isospathulenol (14.63\%), spathulenol (13.45\%), $\alpha$-terpineol (13.28\%), limonene (10.92\%), terpinolene $(10.89 \%)$, $\beta$-myrcene $(6.92 \%)$, ethyl pentadecanoate $(6.15 \%), \beta$-pinene $(4.98 \%)$, and caryophyllene oxide $(4.01 \%)$ were found as major chemical compounds. $P$. atlantica inhibits cell proliferation in $\mathbf{A 5 4 9}$ cell lines in a time (24 h) and dose-dependent manner $(0.5-500 \mu \mathrm{g} / \mathrm{mL})$. After $24 \mathrm{~h}$ of treatment with $P$. atlantica, the cell viability of A549 cell lines ranged from 93.01 \pm 5.24 to $57.69 \pm 4.15 \%$ for concentrations of $0.5-500 \mu \mathrm{g} / \mathrm{mL}$, respectively. This study expands the knowledge of the chemical composition of $P$. atlantica fruits and provides scientific evidence for its possible use as an anticancer medicine. The substantial anticancer activity of $P$. atlantica fruits may be due to the presence of isospathulenol, spathulenol, $\alpha$-terpineol, limonene, terpinolene, $\beta$-myrcene, ethyl pentadecanoate, $\beta$-pinene, and caryophyllene oxide.
\end{abstract}

Index Terms-Pistacia atlantica var. kurdica; Anacardiaceae; Cancer; Gas chromatography-mass spectroscopy; A549 cell lines; (3-4,5 dimethylthiazol-2yl2,5-diphenyl tetrazolium bromide) assay.

\section{INTRODUCTION}

Pistacia atlantica Desf. (Family: Anacardiaceae) is the most common species of this genus and is abundantly

ARO-The Scientific Journal of Koya University

Vol. IX, No.2 (2021), Article ID: ARO.10868, 5 pages

DOI: $10.14500 /$ aro. 10868

Received: 05 September 2021; Accepted: 06 December 2021

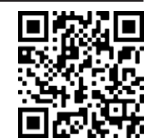

Regular research paper: Published: 15 December 2021

Corresponding author's e-mail: javed.ahamad@tiu.edu.iq

Copyright (C) 2021 Raad A. Kaskoos, Javed Ahamad, Subasini

Uthirapathy. This is an open access article distributed under the

Creative Commons Attribution License. found in Iraq, Syria, Iran, and Turkey (Sharifi, 2014). $P$. atlantica Desf. contains four prominent varieties or subspecies, and it includes $P$. atlantica var. kurdica, $P$. atlantica var. cabulica, $P$. atlantica var. mutica, and $P$. atlantica var. atlantica (Ahmed, et al., 2021). P. atlantica var. kurdica is native to Kurdistan Region of Iraq and mostly found wildly in Shaqlawa and Ranya districts of Kurdistan Region. P. atlantica subsp. kurdica is commonly known as Dar qezwan or Dareben in Kurdish and Atlas in English (Ahmed, 2017). P. atlantica var. kurdica is known as a potent antioxidant plant (Ben Ahmed, et al., 2016; Gourine, et al., 2010). It also has several bioactivities such as antimicrobial (Benhammou, Bekkara and Panovska, 2008; Sharifi and Hazell, 2012), antihyperglycemic (Kasabri, Afifi and Hamdan, 2011), cytotoxic (Hamelian, et al., 2018), and antiviral (Karimi, Moradi and Gafourian, 2020). Lung cancer has emerged as a major cause of cancer-related deaths worldwide, and smoking is considered as the primary cause. Adenocarcinoma, squamous cell carcinoma, and large cell carcinoma are the three types of lung cancer (Collins, et al., 2007). Lung cancer treatment varies based on the nature and stage of the tumor and can range from surgical resection to chemotherapy. Chemotherapy and surgical resection have both been linked to serious side effects. That's why the treatment of lung cancer needs palliative therapy along with chemotherapy (Jones and Baldwin, 2018). Medicinal plants are known to have anticancer activity in in vitro, in vivo, and clinical studies (Gezici and Şekeroğlu, 2019; Ahamad, et al., 2019). The present study is aimed to determine the chemical composition of ethanolic extract of $P$. atlantica var. kurdica fruits by gas chromatography-mass spectrometry method and also to evaluate its cytotoxic activity in A549 (human lung cancer) cell lines.

\section{Materials AND Methods}

\section{A. Plant Materials and Chemicals}

The fresh fruits of $P$. atlantica var. kurdica $(1 \mathrm{~kg})$ were collected in March 2021 from Shaqlawa, Kurdistan Region, Iraq. The authenticity of all the accession was ascertained by Dr. Raad A Kaskoos, Department of Pharmacy, Al-Manara College for 
Medical Science, Amarah, Iraq. The plant sample was archived for future reference in the Faculty of Pharmacy, Tishk International University, Erbil, Iraq (voucher number: PRL/2021/05).

A549 (human lung cancer) cell lines were procured from National Centre for Cell Sciences, Pune, India. Dulbecco's Modified Eagle Medium (DMEM), fetal bovine serum (FBS), and antibiotic solution were procured from Gibco (USA), whereas dimethyl sulfoxide (DMSO) and (3-4,5-dimethylthiazol-2yl-2,5-diphenyl tetrazolium bromide) (MTT) were from Sigma-Aldrich (USA), and HiMedia provided $1 \times$ phosphate-buffered saline (PBS) (India). Tarson provided a 96-well tissue culture plate and a wash beaker (India). All of the other chemicals and solvents were of analytical grade.

\section{B. Preparation of Ethanolic Extract of P. atlantica}

The fresh fruits of $P$. atlantica were pulverized in a mixed grinder and then extracted in an ultrasonicator (Elma, Germany). The pulverized fruits of $P$. atlantica were placed in a stoppered conical flask and extracted for $30 \mathrm{~min}$ with ethanol $(250 \mathrm{~mL})$ in an ultrasonicator at $30^{\circ} \mathrm{C}$ temperature. After filtering, the extract was treated with $5 \mathrm{~g}$ of activated charcoal and filtered again. The filtrate is concentrated in a rotary evaporator (Buchi, Switzerland) at $35^{\circ} \mathrm{C}$. The concentrated ethanolic extract was then air-dried, and the dried ethanolic extract was kept in the refrigerator at $2-4^{\circ} \mathrm{C}$ until needed.

\section{GC-MS Analysis and Identification of Chemical Constituents}

The GC-MS method was used to analyze the chemical composition of an ethanolic extract of $P$. atlantica fruits. The test sample was analyzed on Agilent Bench Top GC-MS (Agilent Technologies, Wilmington, DE, USA) equipment using a DB-5 glass capillary column with specification of $30 \mathrm{~m} \times 0.25 \mathrm{~mm}$ i.d.; film thickness of $0.25 \mu \mathrm{m}$. Helium was used as a carrier gas, and the flow rate was fixed at $1 \mathrm{~mL} / \mathrm{min}$. The oven temperature was set to $50^{\circ} \mathrm{C}$ for $1 \mathrm{~min}$ and then isothermally maintained at $320^{\circ} \mathrm{C}$ for $2 \mathrm{~min}$, whereas the injector port temperature was kept at $280^{\circ} \mathrm{C}$. The split ratio was kept at $1: 5$, and the $0.1 \mu \mathrm{L}$ of $P$. atlantica ethanolic extract in DMSO was injected. Data were collected at 70 $\mathrm{eV}$ with $1.5 \mathrm{~s}$ scanning durations in the mass range of 50$1000 \mathrm{amu}$ and a run time of $37 \mathrm{~min}$. ChemStation software was used to handle the chromatography and mass spectra.

The individual chemical constituents were identified by comparing their Kovats index (K.I.) to those found in the literature and the mass fragmentation pattern of spectra obtained by GC-MS, and they were compared to those stored in the spectrometer database of NIST, NBS 54 K.L, WILEY8 libraries, and published literature for further identification of chemical constituents (Adams, 2007; Ali, 2001; Gourine, et al., 2010; Delazar, Reid and Sarker, 2004; Farhoosh, Tavakoli and Khodaparast, 2008). The area of the individual peaks was used to calculate the percent composition of each component.

\section{Cytotoxic activity of $P$. atlantica var. kurdica}

The potential cytotoxic activity of $P$. atlantica ethanolic extract (for concentration range $0.5-500 \mu \mathrm{g} / \mathrm{mL}$ ) against A549 cell lines (human lung cancer) was assessed using the MTT assay. The assay was performed by the method described by Marquez, et al. (2020). A549 cell lines were cultured in liquid medium (DMEM) supplemented with 10\% FBS, $100 \mu \mathrm{g} / \mathrm{mL}$ penicillin, and $100 \mu \mathrm{g} / \mathrm{mL}$ streptomycin, and kept at $37^{\circ} \mathrm{C}$ in a $5 \% \mathrm{CO}_{2}$ atmosphere. Trypsinization was used to extract the cultured A549 cells, which were then pooled in a $15 \mathrm{~mL}$ tube. The cells were then plated at a density of $1 \times 10^{5}$ cells $/ \mathrm{mL} /$ well $(200 \mu \mathrm{L})$ in a 96 -well plate in DMEM medium containing $10 \% \mathrm{FBS}$ and $1 \%$ antibiotic solution for $24-48 \mathrm{~h}$ at $37^{\circ} \mathrm{C}$. In a serum-free DMEM medium, the cells were rinsed with sterile PBS and treated with $P$. atlantica ethanolic extract. Each sample was replicated 3 times, and the cells were cultured for $24 \mathrm{~h}$ at $37^{\circ} \mathrm{C}$ in a humidified $5 \%$ $\mathrm{CO}_{2}$ incubator. MTT $(20 \mu \mathrm{L}$ at conc. of $5 \mathrm{mg} / \mathrm{mL})$ was added to each well after the incubation period, and the cells were incubated for another 2-4 h until purple precipitates were visible under an inverted microscope. Finally, the medium was aspirated out of the wells together with MTT and rinsed with $1 \times$ PBS. DMSO $(100 \mu \mathrm{L})$ was also added to dissolve formazan crystals, and the plate was agitated for 5 minutes. Using a microplate reader (Thermo Fisher Scientific, USA), the absorbance of each well was measured at $570 \mathrm{~nm}$. The percent cell viability was calculated using the following formula:

$$
\text { Cell viability }(\%)=\frac{\mathrm{OD} \text { test }}{\mathrm{OD} \text { control }} \times 100
$$

\section{RESULTS AND DiscUSSION}

\section{A. GC-MS Analysis of P. atlantica var. kurdica}

The GS-MS analysis was performed to identify different chemical constituents present in ethanolic extract of P. atlantica var. kurdica found in Iraqi Kurdistan. The GCMS analysis of ethanolic extract of $P$. atlantica yielded 33 chemical compounds which constitute about $99.95 \%$ of total chemical compounds (Table 1 and Fig. 1). The major chemical compounds of $P$. atlantica var. kurdica were identified as isospathulenol (14.63\%), spathulenol (13.45\%), $\alpha$-terpineol (13.28\%), limonene (10.92\%), terpinolene $(10.89 \%), \beta$-myrcene $(6.92 \%)$, ethyl pentadecanoate $(6.15 \%), \beta$-pinene $(4.98 \%)$, and caryophyllene oxide (4.01\%). The other chemical compounds present in $P$. atlantica var. kurdica were cis-limonene oxide $(2.18 \%)$, isobutyl hexanoate $(2.19 \%)$, epiglobulol $(2.02 \%)$, phytol (1.90\%), and globulol (1.29\%). The minor chemical compounds which are less than $1 \%$ also listed in Table 1 . As $P$. atlantica is found in different parts of the world, its chemical composition has been analyzed by several researchers. Delazar, et al. (2004), studied the chemical composition of oleoresin from $P$. atlantica var. mutica by GC-MS method growing in Iran, and the results show the presence of $\alpha$-pinene $(70 \%)$ limonene oxide (9\%), citral (5.72\%), and myrtenol $(5.31 \%)$ as major constituents. Gourine, et al. (2010), studied 34 samples of $P$. atlantica Desf. from different locations of Algeria by GC-MS and found $\alpha$-pinene (5.54-66.61\%), camphene (0.75-20.85\%), 


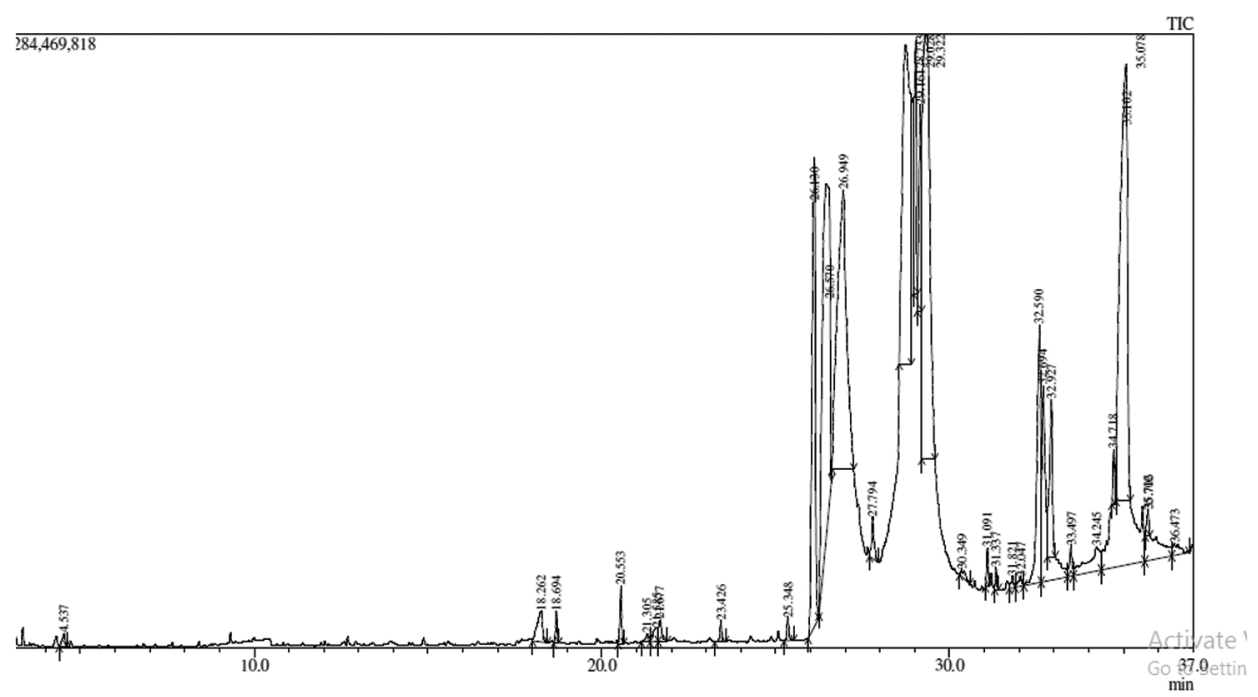

Fig. 1. Gas chromatography-mass spectroscopy spectra of ethanolic extract of Pistacia atlantica var. kurdica fruits.

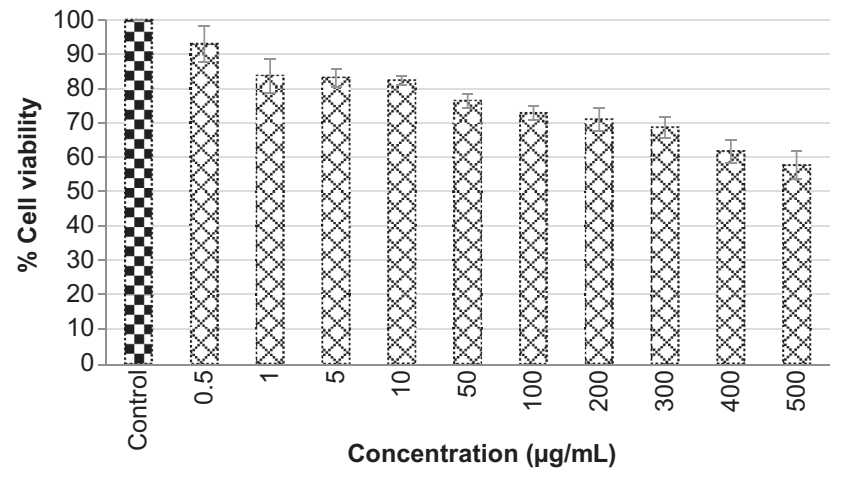

Fig. 2. The cell cytotoxicity produced by ethanolic extract of Pistacia atlantica var. kurdica fruits (represented as \% cell viability) (data were presented as mean of triplicate determinations \pm SD).

$\beta$-pinene $\quad(1.09-13.12 \%), \quad p$-cymene $\quad(0.39-10.19 \%), \quad$ and terpinene-4-ol (0.42-15.97\%) as major chemical constituents. Mecherara-Idjeri, et al. (2008), studied the chemical composition of leaf, fruit, and gall essential oils of $P$. atlantica Desf. from Algeria, and the major chemical constituents were found as $\alpha$-pinene (32.6-54.7\%) and $\beta$-pinene (8.0-20.2\%). The above research studies were performed on $P$. atlantica var. mutica and other subspecies of it, and also plants were studied from different geographical locations such as Iran and Algeria. The current study is the first study on P. atlantica var. kurdica growing in Iraqi Kurdistan and shows the presence of isospathulenol, spathulenol, $\alpha$-terpineol, limonene, terpinolene, $\beta$-myrcene, ethyl pentadecanoate, $\beta$-pinene, and caryophyllene oxide as major chemical constituents. The variation in chemical constituents and their amounts may be due to differences in geographical locations, altitude, soil, rainfall, etc. (Ahamad and Uthirapathy, 2021a and b).

\section{B. Cytotoxic Activity of P. atlantica var. kurdica}

The cytotoxic activity of $P$. atlantica var. kurdica was assessed using A549 (human lung cancer) cell lines by MTT test. Figs. 2 and 3 show the results of the MTT assay.
TABLE I

Chemical Composition of Ethanolic Extract of Pistacia atLantica Var. KURDICA FRUITS

\begin{tabular}{|c|c|c|c|}
\hline Name of chemical compound & RT & RI & \% composition \\
\hline 4-Hydroxyhexan-3-one & 4.537 & 846 & 0.15 \\
\hline Ethylene glycol monoisobutyl ether & 18.262 & 878 & 0.72 \\
\hline Heptanal & 18.694 & 904 & 0.24 \\
\hline Tricyclene & 20.553 & 920 & 0.43 \\
\hline$\alpha$-Thujene & 21.305 & 925 & 0.12 \\
\hline$\alpha$-Pinene & 21.585 & 934 & 0.32 \\
\hline Camphene & 21.677 & 946 & 0.27 \\
\hline Verbenene & 23.426 & 960 & 0.16 \\
\hline Sabinene & 25.348 & 976 & 0.20 \\
\hline$\beta$-Pinene & 26.130 & 980 & 4.98 \\
\hline$\beta$-Myrcene & 26.570 & 992 & 6.92 \\
\hline Limonene & 26.949 & 1032 & 10.92 \\
\hline cis-Ocimene & 27.794 & 1039 & 0.44 \\
\hline Terpinolene & 28.733 & 1088 & 10.89 \\
\hline cis-Limonene oxide & 29.028 & 1137 & 2.18 \\
\hline Isobutyl hexanoate & 29.161 & 1160 & 2.19 \\
\hline$\alpha$-Terpineol & 29.322 & 1180 & 13.28 \\
\hline 3Z-Hexenyl 3-methylbutanoate & 30.349 & 1231 & 0.15 \\
\hline Tetradecane & 31.091 & 1402 & 0.26 \\
\hline$\beta$-Caryophyllene & 31.337 & 1432 & 0.14 \\
\hline$\alpha$-Humulene & 31.821 & 1458 & 0.13 \\
\hline$\beta$-Curcumene & 32.047 & 1517 & 0.16 \\
\hline Caryophyllene oxide & 32.590 & 1573 & 4.01 \\
\hline Ethyl pentadecanoate & 32.694 & 1991 & 6.15 \\
\hline Epiglobulol & 32.927 & 2026 & 2.02 \\
\hline Methyl elaidate & 33.497 & 2080 & 0.33 \\
\hline Globulol & 34.245 & 2092 & 1.29 \\
\hline Viridiflorol & 34.718 & 2100 & 0.37 \\
\hline Spathulenol & 35.078 & 2140 & 13.45 \\
\hline Isospathulenol & 35.102 & 2241 & 14.63 \\
\hline (E)9-Hexadecen-1-ol & 35.706 & 2413 & 0.24 \\
\hline Phytol & 35.712 & 2620 & 1.90 \\
\hline Palmitic acid & 36.473 & 2915 & 0.31 \\
\hline
\end{tabular}

Where, RT: Retention time and KI: Kovats index

P. atlantica inhibits cell proliferation of A549 cell lines in a time $(24 \mathrm{~h})$ and dose $(0.5-500 \mu \mathrm{g} / \mathrm{mL})$ dependent manner. After $24 \mathrm{~h}$ of treatment with $P$. atlantica extract, 


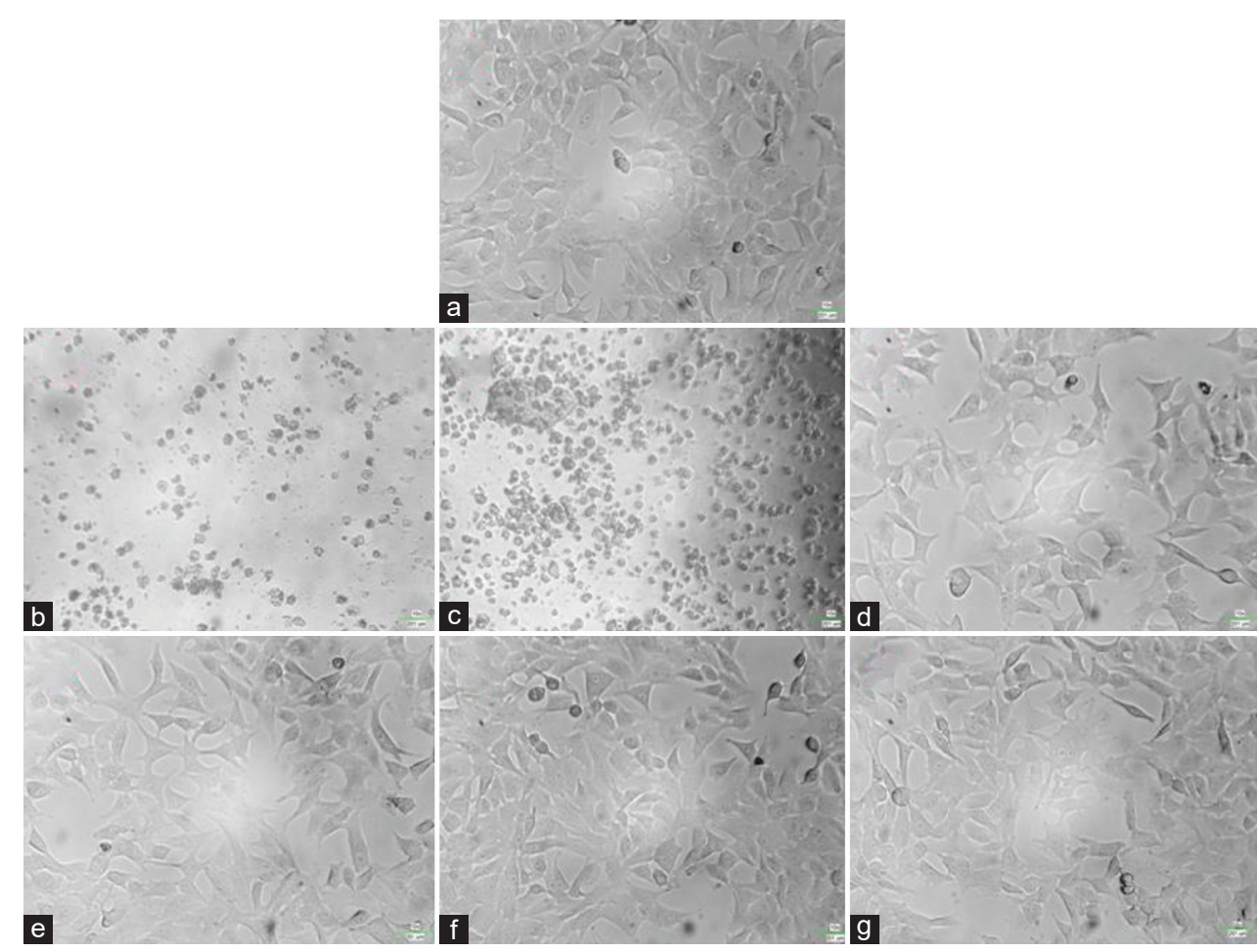

Fig. 3. Cell cytotoxicity produced by ethanolic extract of Pistacia atlantica var. kurdica fruits against human lung cancer A549 cell lines. Where, figure

(a): Control cells; and figure b to g: P. atlantica var. kurdica ethanolic extract: ([b]: $500 \mu \mathrm{g} / \mathrm{mL}$, [c]: $300 \mu \mathrm{g} / \mathrm{mL},[\mathrm{d}]: 100 \mu \mathrm{g} / \mathrm{mL},[\mathrm{e}]: 50 \mu \mathrm{g} / \mathrm{mL}$,

[f]: $10 \mu \mathrm{g} / \mathrm{mL}$, and [g]: $0.5 \mu \mathrm{g} / \mathrm{mL})$.

the cell viability of A549 cell lines ranged from 93.01 \pm 5.24 to $57.69 \pm 4.15 \%$ at concentrations of $0.5-500 \mu \mathrm{g} /$ $\mathrm{mL}$, respectively (Figs. 2 and 3). For A549 cell lines, the $\mathrm{IC}_{50}$ value of $P$. atlantica ethanolic extract was $21.91 \mu \mathrm{g} /$ $\mathrm{mL}$ after $24 \mathrm{~h}$. Even when the incubation was extended to $24 \mathrm{~h}$, the untreated A549 cells maintained their original morphology and intimate contact with each other, as shown in Fig. 3A. After $24 \mathrm{~h}$ ' treatment with ethanolic extract of $P$. atlantica, the A549 cells lost their natural form. The elongated spindle-shaped morphology of the A549 cell lines had vanished. Suspension cells (dead cells) were observed after the treatment was extended to $48 \mathrm{~h}$, and more suspension cells were observed after $24 \mathrm{~h}$ (Fig. 3B-G). The MTT test for cell cytotoxicity has long been used to screen medicinal plants with possible anticancer activity (Ahamad, et al., 2019).

\section{CONCLUSION}

The GC-MS analysis of ethanolic extract of $P$. atlantica var. kurdica fruits shows the presence of 33 chemical constituents, and isospathulenol, spathulenol, $\alpha$-terpineol, limonene, terpinolene, $\beta$-myrcene, ethyl pentadecanoate, $\beta$-pinene, and caryophyllene oxide were found as major chemical constituents. The ethanolic extract of $P$. atlantica var. kurdica shows time- and dose-dependent inhibition of A549 cell lines. The present study explores the chemical composition of $P$. atlantica var. kurdica fruits and provides the scientific basis for its potential use as an anticancer medicine.

\section{ACKNOWLEDGMENT}

We gratefully acknowledge the Tishk International University, Erbil, Iraq, for providing research facilities. We also acknowledge Trichy Research Institute of Biotechnology Pvt. Ltd., Trichy, Tamil Nadu, India, for providing the research facilities.

\section{REFERENCES}

Adams, R.P., 2007. Identification of Essential Oil Components by Gas Chromatography/Mass Spectrometry, $4^{\text {th }}$ ed. Allured Publishing, Carol Stream, IL, USA.

Ahamad, J. and Uthirapathy, S., 2021a. Chemical characterization and antidiabetic activity of essential oils from Pelargonium graveolens leaves. ARO The Scientific Journal of Koya University, 9(1), pp.109-113.

Ahamad, J., Toufeeq, I., Khan, M. A., Ameen, M.S.M., Anwer, E.T., Uthirapathy, S., Mir, S.R., Ahmad, J., 2019. Oleuropein: A natural antioxidant molecule in the treatment of metabolic syndrome. Phytotherapy Research, 33(12), pp.3112-3128.

Ahamad, J., Uthirapathy, S., Ameen, M.S.M. and Anwer, E.T., 2019. Essential oil composition and antidiabetic, anticancer activity of Rosmarinus officinalis L. leaves from Erbil (Iraq). Journal of Essential Oil Bearing Plants, 22(6), pp.1544-1553.

Ahmed, H.M., 2017. Traditional uses of Kurdish medicinal plant Pistacia atlantica subsp. kurdica Zohary in Ranya, Southern Kurdistan. Genetic Resources and Crop Evolution, 64, pp.1473-1484.

Ahmed, Z.B., Yousfi, M., Viaene, J., Dejaegher, B., Demeyer, K. and Heyden, Y.V., 2021. Four Pistacia atlantica subspecies (atlantica, cabulica, kurdica and mutica): A review of their botany, ethnobotany, phytochemistry and pharmacology. Journal of Ethnopharmacology, 265, p.113329.

Ali, M., 2001. Techniques in Terpenoid Identification, Birla Publication, 
New Delhi, India, pp.4-51.

Ben Ahmed, Z., Yousfi, M., Viaene, J., Dejaegher, B., Demeyer, K., Mangelings, D. and Vander Heyden, Y., 2016. Antioxidant activities of Pistacia atlantica extracts modelled as a function of chromatographic fingerprints in order to identify antioxidant markers. The Microchemical Journal, 128, pp.208-217.

Benhammou, N., Bekkara, F.A. and Panovska, T.K., 2008. Antioxidant and antimicrobial activities of the Pistacia lentiscus and Pistacia atlantica extracts. African Journal of Pharmacy and Pharmacology, 2(2), pp.22-28.

Collins, L.G., Haines, C., Perkel, R. and Enck, R.E., 2007. Lung cancer: Diagnosis and management. American Family Physician, 75(1), pp.56-63.

Delazar, A., Reid, R.G. and Sarker, S.D., 2004. GC-MS analysis of the essential oil from the oleoresin of Pistacia atlantica var. mutica. Chemistry of Natural Compounds, 40, pp.24-27.

Farhoosh, R., Tavakoli, J. and Khodaparast, M.H.H., 2008. Chemical composition and oxidative stability of kernel oils from two current subspecies of Pistacia atlantica in Iran. Journal of the American Oil Chemists Society, 85, pp.723-729.

Gezici, S. and Şekeroğlu, N., 2019. Current perspectives in the application of medicinal plants against cancer: Novel therapeutic agents. Anti-Cancer Agents in Medicinal Chemistry, 19(1), pp.101-111.

Gourine, N., Yousfi, M., Bombarda, I., Nadjemi, B., Stocker, P. and Gaydou, E.M. 2010. Antioxidant activities and chemical composition of essential oil of Pistacia atlantica from Algeria. Industrial Crops and Products, 31, pp.203-208.

Hamelian, M., Hemmati, S., Varmira, K. and Veisi, H., 2018. Green synthesis, antibacterial, antioxidant and cytotoxic effect of gold nanoparticles using Pistacia atlantica extract. Journal of the Taiwan Institute of Chemical Engineers, 93, pp.21-30.
Jones, G.S. and Baldwin, D.R., 2018. Recent advances in the management of lung cancer. The Clinical Medicine (Lond), 18(2), pp.S41-S46.

Karimi, A., Moradi, M.T. and Gafourian, A., 2020. In vitro anti-adenovirus activity and antioxidant potential of Pistacia atlantica Desf. leaves. Research Journal of Pharmacognosy, 7(2), pp.53-60.

Kasabri, V., Afifi, F.U. and Hamdan, I., 2011. In vitro and in vivo acute antihyperglycemic effects of five selected indigenous plants from Jordan used in traditional medicine. Journal of Ethnopharmacology, 133(2), pp.888-896.

Marquez, C.M.D., Garcia, J.G., Antonio, J.G., Jacinto, S.D. and Velarde, M.C. 2020. Alangium longiflorum Merr. leaf extract induces apoptosis in A549 lung cancer cells with minimal NFKB transcriptional activation. Asian Pacific Journal of Cancer Prevention, 21(8), pp.2453-2461.

Mecherara-Idjeri, S., Hassani, A., Castola, V. and Casanova, J., 2008. Composition of leaf, fruit and gall essential oils of Algerian Pistacia atlantica Desf. The Journal of Essential Oil Research, 20, pp.215-219.

Najibullah, S.N.M., Ahamad, J., Aldahish, A.A., Sultana S. and Sultana, S., 2021b. Chemical characterization and $\alpha$-glucosidase inhibitory activity of essential oil of Lavandula angustifolia flowers. Journal of Essential Oil Bearing Plants, 24(3), pp.431-438.

Sharifi, M.S. and Hazell, S.L., 2012. Isolation, analysis and antimicrobial activity of the acidic fractions of Mastic, Kurdica, Mutica and Cabolica gums from genus Pistacia. Global Journal of Health Science, 4, pp.217-228.

Sharifi, M.S., 2014. Chapter five Pistacia atlantica Kurdica. In: Perspectives on Kurdistan's Economy and Society in Transition. Vol. 2. Cambridge Scholars Publishing, United Kingdom, pp.64-83. 